\title{
DETERMINAN DAN KONSEKUENSI DARI MOTIVASI (STUDI EMPIRIS PADA RUMAH SAKIT SWASTA DI KOTA MATARAM)
}

\author{
Sulaimiah ${ }^{1}$ \\ H. Zainal Abidin ${ }^{1}$ \\ Wahidatul Husnaini ${ }^{2}$ \\ Zuhrotul Isnaini' ${ }^{2}$ \\ Heni Herawaty ${ }^{3}$
}

\begin{abstract}
The objective of this research is to examine empirically determinant of motivation and its consequence. The consequence of motivation are satisfaction and performance. This research used purposive sampling in data collection. Data were collected from 150 nurse in Harapan Keluarga Hospital. Data analysis used AMOS. The finding sugest that : (1) leadership is positive influence to motivation and satisfaction, (2) compensation is positive influence to motivation, (3) compensation is negative influence to satisfaction, (4) work environment not influence to motivation but influence to satisfcation, (5) stres is not influence to satisfaction and performance. (6) Satisfaction is not mediating the relationship between stress and performance. (7) motivation is not influence to performance. (8) Satisfaction is not mediating the relationship between motivation and performance
\end{abstract}

Keywords: Leadership, compensation, work environment, stress, motivation, satisfaction, performance

\section{Pendahuluan}

\subsection{Latar Belakang}

Motivasi merupakan salah satu faktor yang menentukan seseorang untuk bekerja. Menurut Potu (2013) Apabila motivasi baik, maka kinerja karyawan akan meningkat. Motivasi yang tinggi akan menyebabkan pekerjaan yang diberikan akan diselesaikan secara bertanggungjawab sebaliknya jika seseorang mempunyai kemampuan yang maksimal serta disertai dengan kelengkapan fasilitas yang memadai, namun jika tidak ada motivasi untuk melakukan pekerjaan tersebut maka pekerjaan itu tidak akan berjalan sebagaimana yang diharapkan. (Sari, dkk. 2012). Motivasi itu bisa muncul dari diri sendiri maupun dari luar. Motivasi yang berasal dari luar bisa disebabkan oleh gaya kepemimpinan, kompensasi yang diberikan di tempat kerja serta lingkungan kerja itu sendiri. Motivasi yang tinggi akan menyebabkan kepuasan bagi diri sendiri sehingga mengakibatkan kinerja meningkat. Menurut Herzberg et. all (1959) yang dirangkum oleh Adrian dan Andreas (2009) sumber kepuasan kerja karyawan adalah gaji (kompensasi), hubungan dengan rekan kerja, supervisi dari pimpinan, kondisi kerja (lingkungan) dan kebijakan perusahaan.

Motivasi yang tinggi akan mempengaruhi kinerja melalui kepuasan, jika motivasi tinggi maka kepuasan juga tinggi yang pada ahirnya mempengaruhi kinerja. Menurut Surati dkk (2013) kepuasan kerja karyawan merupakan faktor yang paling dominan karena organisasi yang memberikan kenyamanan kepada karyawan akan menyebabkan karyawan mengerjakan pekerjaannya dengan rasa tanggungjawab bahkan disiplin yang tinggi sehingga akhirnya mempengaruhi organisasi. Hal yang sama diungkapkan oleh Stringer et.all (2011) bahwa motivasi berhubungan dengan kepuasan kerja dan sangat tergantung dari reward seperti bonus dan promosi

\footnotetext{
${ }^{1}$ Staf Pengajar Jurusan Manajemen FEB UNRAM

${ }^{2}$ Staf Pengajar Jurusan Akuntansi FEB UNRAM

${ }^{3}$ Pegawai sebuah Perusahaan di Mataram
} 
(Van et. all 2005). Ketika bonus atau kompensasi tinggi menyebabkan orang termotivasi untuk bekerja.

Namun tidak selamanya kepuasan itu tinggi tergantung dari penyebab kepuasan itu sendiri. Kepuasan sangat dipengaruhi oleh gaya kepemimpinan, kompensasi di tempat kerja, lingkungan kerja serta stres. Mayfield and Milton (2010) menyebutkan bahwa kepemimpinan pada level menengah-rendah (Midle Low) berhubungan positif dan mempengaruhi kinerja dan kepuasan kerja karyawannya. Hal yang berlawanan diungkapkan oleh Sulaimiah dkk (2013) bahwa kepemimpinan tidak mempengaruhi kinerja yang disebabkan pimpinan tidak pernah mencampuri urusan pekerjaan bawahannya selama pegawainya bekerja sesuai dengan aturan/tugas yang diberikan begitu juga dengan bawahan bekerja sesuai dengan aturan/tugas yang diberikan atasan.

Kemampuan berkomunikasi seorang pemimpin merupakan salah satu faktor yang diperlukan di lingkungan kerja. Menurut Borchgrevink (2004), Kramer (2006), Mayfield and Mayfield (2007) kualitas komunikasi pimpinan mempengaruhi kepuasan kerja dan kinerja. Hal yang sama diungkapkan oleh Hamidi dan Zahra (2010) bahwa karyawan puas dengan pekerjaan dan pimpinan mereka tetapi mereka tidak puas jika mereka dipromosikan. Menurut Potu (2013) karyawan termotivasi untuk bekerja dan menghasilkan karya yang baik jika mendapatkan pujian dari pimpinan, perhatian dari pimpinan, dan juga mendapatkan bonus dan tunjangan dari perusahaan.

Karyawan dalam hal ini perawat akan puas terhadap pekerjaan yang diberikan jika stress kerja masih bisa dikendalikan oleh karyawan itu sendiri. Menurut Vafaei (2000), Zahedi, Palahang dan Ghafari (2000) stres kerja berhubungan langsung dan signifikan dengan kepuasan kerja dan masing-masing komponen kepuasan kerja. Jika komponen masing-masing kepuasan kerja meningkat maka total kepuasan juga meningkat. Kepuasan kerja berhubungan positif dengan level kinerja (Farzadfar et al., 2005). Raeissi and Tavakoli (2002) menemukan bahwa pada tingkat stress yang moderat dapat meningkatkan kinerja dan pada tingkat stress yang normal akan menghasilkan kinerja yang efektif.

\subsection{Tujuan Penelitian}

Sebagaimana diuraikan dalam latar belakang maka penelitian ini bertujuan untuk menganalisis serta memberikan bukti secara empiris faktor yang menentukan motivasi serta konsekuensinya.

\subsection{Urgensi Penelitian}

Mengingat motivasi itu bisa muncul dari luar dan dari dalam individu seperti kepemimpin, kompensasi, lingkungan. Motivasi akan berdampak pada kinerja dan kepuasan. Kondisi dilapangan menunjukkan adanya gaji yang tidak transparan dan kurang penghargaan bagi karyawan yang beprestasi.

\section{Tinjauan Pustaka}

\subsection{Kepemimpinan dan Pengaruhnya Terhadap Motivasi dan Kepuasan}

Vecchio (2003 : 144) maupun Ivancevich et. al (2008 : 413) mendefinisikan kepemimpinan sebagai proses mempengaruhi orang lain dalam hal ini adalah anggota kelompok untuk mengerjakan sesuatu sesuai dengan yang diinginkan untuk mencapai tujuan organisasi yang relevan. Kinerja karyawan maupun suatu organisasi dipengaruhi oleh pimpinan. Kemampuan komunikasi seorang pemimpin dalam suatu organisasi merupakan faktor yang menentukan hubungan antara pekerjaan dengan reward yang akan diberikan kepada para karyawannya. (Conger, 1991; Goleman et al., 2002, 2004; Henderson et al., 2006; Henderson et al., 2008; Mayfield and Mayfield, 2007; Sullivan, 1988).

Kesuksesan suatu individu maupun team yang ditunjukkan dengan kepuasan tergantung dari keberadaan pimpinan. Seperti yang diungkapkan oleh Bass dan Avolio (1990) dan Yukl (1989) 
bahwa atasan (pimpinan) sangat berperan untuk mendorong karyawan sehingga bisa menghasilkan kinerja yang optimal. Hal yang sama diungkapkan oleh Fisher dan Rubenstein yang dikutip Sulaimiah (2005) dan Adianto, dkk (2005) bahwa pimpinan sebagai penanggungjawab organisasi perlu menciptakan suatu hubungan antara para karyawan sehingga memberikan dampak pada kinerja karyawan. Kepuasan kerja dipengaruhi pengarahan yang diberikan oleh atasan (kepemimpinan). Hasil penelitian Mayfield dan Milton (2010) menunjukkan pimpinan level Moderate-Low mempengaruhi kepuasan dan kinerja bawahannya.

H1 : Kepemimpinan berpengaruh terhadap Motivasi

H2 : Kepemimpinan berpengaruh terhadap Kepuasan

2.2. Pengaruh Kompensasi terhadap Motivasi dan Kepuasan

Salah satu yang mempengaruhi kinerja individu dalam suatu organisasi adalah sistem reward (Ivanchevich, et all. 2008 : 17). Reward yang dimaksud disini adalah kompensasi. Semakin tinggi kompensasi maka motivasi juga akan tinggi, motivasi tinggi kepuasan juga tinggi yang pada akhirnya mempengaruhi kinerja. Penelitian Potu (2014) menunjukkan perusahaan harus membuat sebuah sistem "reward" yang baik untuk karyawan sehingga mereka dapat termotivasi untuk bekerja dan menghasilkan karya yang baik. Karyawan akan termotivasi jika mendapatkan bonus dan tunjangan dari perusahaan.

Menurut Teori Herzberg (1966), salah satu faktor yang mendorong individu untuk berusaha mencapai kepuasan dan menjauhkan diri dari ketidakpuasan adalah imbalan (kompensasi). Ketika kompensasi tinggi maka kepuasan juga akan tinggi

\section{H3 : Kompensasi berpengaruh terhadap Motivasi}

$\mathrm{H} 4$ : Kompensasi berpengaruh terhadap Kepuasan

\subsection{Pengaruh Lingkungan Terhadap Motivasi dan Kepuasan Kerja}

Teori Herzberg (1966) menjelaskan bahwa puas atau tidak puasnya individu salah satunya disebabkan karena lingkungan kerja. Hal yang sama juga diungkapkan oleh Mayfield dan Milton (2010) bahwa motivasi karyawan adalah lingkungan kerja. Kemampuan bekerjasama dengan rekan kerja dan suasana lingkungan yang nyaman akan memotivasi seseorang untuk mengerjakan apa yang seharusnya dikerjakan di tempat kerja (Johansson 2007). Hasil penelitian Arvey et al. (1989) menyebutkan sekitar 30\% kepuasan kerja dipengaruhi oleh faktor lingkungan dan genetik.

Potu (2013) menyebutkan bahwa Lingkungan kerja memberikan pengaruh positif dan signifikan terhadap kinerja karyawan. Lingkungan kerja yang nyaman dan menyenangkan, akan membentuk budaya kerja yang cukup produktif sehingga setiap anggota selalu termotivasi untuk memberikan performa terbaiknya untuk menyelesaikan semua tugas-tugasnya sesuai dengan peran mereka.

\section{H5 : Lingkungan Berpengaruh Terhadap Motivasi}

\section{H6 : Lingkungan Berpengaruh Terhadap Kepuasan Kerja}

\subsection{Pengaruh Stres Terhadap Kepuasan dan Kinerja}

Luthans (2006 : 440) membagi stres menjadi 2 (dua) yaitu (1) sesuatu yang baik yang disebut eustres dan (2) sesuatu yang buruk disebut disstres (stres yang buruk). Ivancevich et all $(2008,224)$ mendefinisikan stres sebagai adapatasi atas respon individu yang dimediasi oleh individu yang berbeda sebagai konsekuensi atas tindakan, situasi atau kejadian yang memberikan tekanan berlebih terhadap seseorang.

Menurut Vecchio (2003 : 265), akibat yang ditimbulkan dari stres akan mempengaruhi emosional karyawan yang pada akhirnya mempengaruhi pekerjaan. Reaksi emosional yang ditimbulkan adalah kepuasan. Kepuasan kerja merupakan salah satu fikiran dan perasaan maupun sikap terhadap pekerjaan. Apabila fikiran, perasaan maupun sikap sudah benar maka tingkat kepuasan tinggi namun sebaliknya kepuasan kerja akan rendah jika dipengaruhi stres yang berlebihan. Sikap dari karyawan terbentuk dari pekerjaan itu sendiri, komunikasi dengan yang lain memainkan peran yang penting. 
Model stress Ivancevich et all $(2008,227)$ menggambarkan stres di tempat kerja tidak selamanya berdampak buruk bagi kinerja individu (karyawan) maupun kinerja organisasional. Pada tingkat tertentu, stres dapat meningkatkan kepuasan kerja dan kinerja (job performance) namun pada tingkat stres yang tinggi akan menyebabkan masalah bagi karyawan diantaranya masalah dengan kesehatan maupun perilaku. Masalah kesehatan seperti tekanan darah tinggi, tingkat kolesterol yang tinggi bahkan dapat menyebabkan sakit jantung. Masalah perilaku seperti perubahan produktivitas, absensi.

\section{H7 : Stres Berpengaruh Terhadap Kepuasan}

\section{H8 : Stres Berpengaruh Terhadap Kinerja Melalui Kepuasan}

\subsection{Pengaruh Motivasi Terhadap Kepuasan dan Kinerja}

Ivancevich et. al (2008 : 113) menyebutkan bahwa teori motivasi menurut Maslow merupakan kebutuhan individu yang diatur dalam suatu hierarki. Orang akan berusaha memuaskan kebutuhan yang lebih mendasar (tingkat rendah) sebelum mengarahkan perilaku menuju kebutuhan dengan tingkat yang lebih tinggi.

Semakin tinggi motivasi seseorang akan meningkatkan kinerja karyawan. Menurut Dwiyanti (2011), pada saat saat tertentu, dalam hal tertentu waktu akhir (dead line) justru dapat meningkatkan motivasi dan menghasilkan prestasi kerja yang tinggi. Hasil penelitian Pramono (2011), Sari, dkk (2012) dan Potu (2013) menujukkan hal yang sama bahwa motivasi berpengaruh signifikan terhadap kinerja karyawan. Karyawan menunjukkan kinerja yang meningkat jika motivasi meningkat.

Menurut Veechio (2003 : 266) : kinerja organisasi seharusnya diukur dengan dimensi orang yaitu return on investment, market share, laba setelah pajak. Banyak alasan yang menentukan kepuasan karyawan dan yang paling banyak adalah alasan moral. Kepuasan kerja mempunyai peranan penting dalam perusahaan terkait dengan kemampuan perusahaan menentukan kualifikasi karyawannya.

\section{H9 : Motivasi Berpengaruh Terhadap Kinerja}

\section{H10 : Motivasi Berpengaruh Terhadap Kinerja melalui Kepuasan}

Berdasarkan hipotesis tersebut, arah maupun hubungan penelitian dapat digambarkan kerangka konseptual sebagai berikut:

\section{Gambar 1 \\ Kerangka Konseptual}

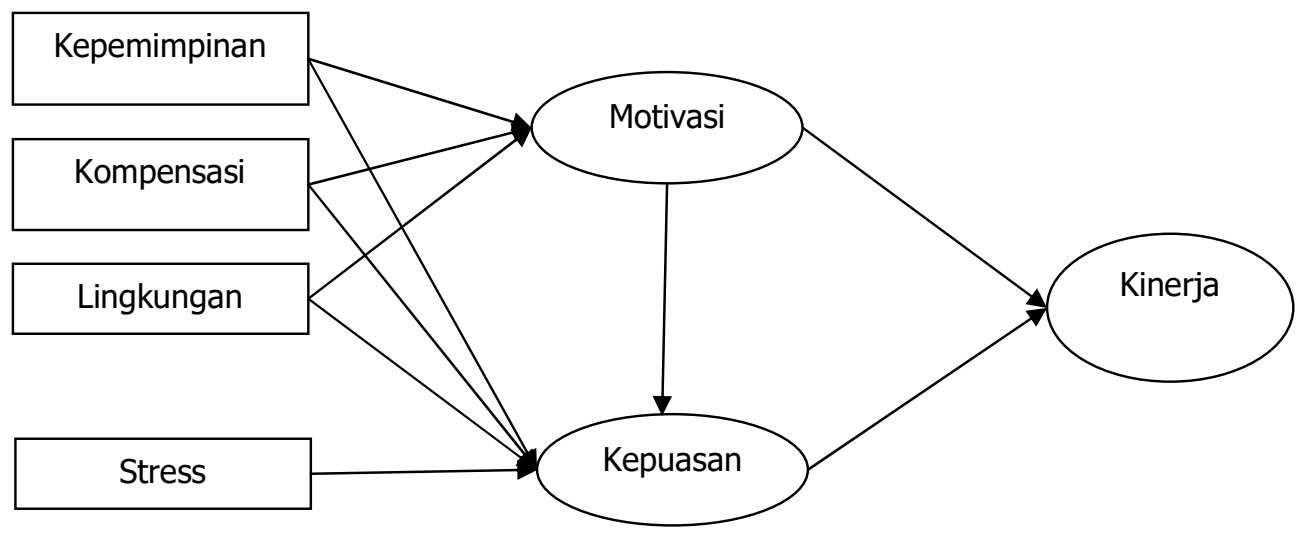




\section{Metode Penelitian}

\subsection{Jenis/Rancangan Penelitian}

Jenis penelitian ini adalah kausalitas karena bertujuan menjelaskan pengaruh atau hubungan (kausal) antar variabel. (Solimun, 2007). Pengaruhantar variabel tersebut dirumuskan dalam bentuk hipotesis penelitian yang akan diuji kebenaranya. Pengujian hipotesis ini menjelaskan fenomena dalam bentuk hubungan antar variabel yang merupakan hubungan kausalitas antar beberapa variabel eksogen (kepemimpinan, kompensasi, lingkungan dan stres) yang mempengaruhi variabel endogen (motivasi, kepuasan dan kinerja).

\subsection{Populasi dan Sampel Penelitian}

Populasi dalam penelitian ini adalah semua perawat di Rumah Sakit Swasta di Kota Mataram. Penelitian ini menggunakan purposive sampling dengan kriteria tertentu. Kriteria responden dalam penelitian ini adalah perawat di bagian rawat inap di Rumah Sakit Swasta di Kota Mataram. Pemilihan Rumah Sakit Swasta karena adanya kompensasi diluar gaji sedangkan pemilihan bagian rawat inap karena adanya stress yang ditimbulkan disebabkan pasien yang mengalami penanganan lebih serius dan terus menerus.

\subsection{Prosedur Pengumpulan Data}

Pengumpulan data dilakukan dengan personally administrated questionnaires atau mail survey. Metode ini dilakukan melalui penyebaran kuesioner berupa daftar pertanyaan (kuesioner) kepada responden dengan pertanyaan terkait (angket terstruktur).

\subsection{Instrumen Penelitian}

Instrumen penelitian yang digunakan dalam penelitian ini merupakan gabungan dari dari beberapa penelitian sebelumnya dan disesuaikan dengan konstruk yang digunakan.

1. Kepemimpinan, merupakan perilaku dan proses individu mempengaruhi orang lain dalam organisasi untuk mencapai tujuan organisasi. Variabel kepemimpinan menggunakan instrumen yang sudah dimodifikasi oleh peneliti dari instrumen yang digunakan oleh Divr et all (2002) dan Rafferty dan Griffin (2004). Kinerja diukur dengan skala likert dengan rentang nilai 1 sampai 5 (mulai dari 1 = sangat tidak setuju sampai 5 = sangat setuju).

2. Kompensasi,imbalan yang diterima oleh karyawan atas tugas yang dilakukan dalam organisasi baik dalam bentuk finansial maupun non finansial. Kompensasi diukur dengan skala likert dengan rentang nilai 1 sampai 5 (mulai dari $1=$ sangat tidak setuju sampai $5=$ sangat setuju).

3. Lingkungan, tempat karyawan melakukan aktivitas setiap hari. Lingkungandiukur dengan skala likert dengan rentang nilai 1 sampai 5 (mulai dari $1=$ sangat tidak setuju sampai $5=$ sangat setuju).

4. Stres kerja, suatu respon adaptif diperantarai oleh karakteristik individual dan suatu proses psikologis individu yang merupakan konsekuaensi dari tindakan atau situasi eksternal atau kejadian yang menempatkan suatu tuntutan khusus baik fisik maupun psikis atas diri seseorang. Variabel Stres kerja menggunakan instrumen yang dipakai oleh Ivancevich dan Matteson (2008). Kinerja diukur dengan skala likert dengan rentang nilai 1 sampai 5 (mulai dari 1 = sangat tidak setuju sampai 5 = sangat setuju).

5. Motivasi, dorongan seseorang untuk melakukan sesuatu. Motivasidiukur dengan skala likert dengan rentang nilai 1 sampai 5 (mulai dari $1=$ sangat tidak setuju sampai $5=$ sangat setuju).

6. Kepuasan Kerja. sikap seorang individu terhadap pekerjaannya. Karyawan dengan tingkat kepuasan kerja yang tinggi menunjukan sikap yang positif terhadap pekerjaanya, sedangkan karyawan yang tidak puas dengan pekerjaannya akan menunjukkan sikap yang negatif terhadap pekerjaannya tersebut.Kepuasan Kerjadiukur dengan skala likert dengan rentang nilai 1 sampai 5 (mulai dari $1=$ sangat tidak setuju sampai 5 = sangat setuju). 
7. Kinerja. Kontribusi karyawan terhadap pencapaian tujuan organisasi. Variabel ini dinilai oleh atasan langsung karyawan yang bersangkutan dengan menggunakan instrumen yang dipakai oleh Crouch dan Yetton (1987) dalam Sulaimiah (2005). Kinerja diukur dengan skala likert dengan rentang nilai 1 sampai 5 (mulai dari 1 = sangat tidak setuju sampai $5=$ sangat setuju).

\subsection{Prosedur Dan Analisis Data 3.6.1. Uji Non Respon Bias}

Pengujian non-response bias dilakukan dengan tujuan untuk melihat apakah jawaban kuesioner yang dikembalikan responden sebelum tanggal yang ditetapkan (cut off) dengan jawaban responden setelah tanggal yang ditetapkan mengembalikan kuesioner (non-response) berbeda. Uji non-response bias menggunakan independent sample $t$ test dengan melihat rata-rata jawaban responden dalam kelompok sebelum dan sesudah tanggal yang telah ditentukan (cut off). Jika P-value $>0.05$ yang artinya sampel penelitian ini memenuhi syarat representasi populasi.

\subsubsection{Uji Kualitas Data}

Hair (2006) menjelaskan bahwa kualitas data yang dihasilkan dari penggunaan instrumen penelitian dapat dievaluasi melalui uji reabilitas dan validitas. Uji tersebut masing-masing untuk mengetahui konsistensi dan akurasi data yang dikumpulkan dari penggunaan instrumen.

\subsubsection{Uji konsistensi atau realibilitas}

Pengujian ini menguji jawaban responden atas instrumen penelitian. Reliabilitas ditentukan dengan koefisien cronbach alpha. Suatu konstruk atau instrumen dikatakan reliabel jika nilai cronbach alpha di atas 0.60 (Hair, 2006).

\subsubsection{Uji validitas}

Uji validitas digunakan untuk mengukur valid tidaknya suatu kuesioner. Indikator untuk menunjukkan validitas konvergen yang signifikan jika koefisien variabel indikator lebih besar dari dua standar errornya (C.R > 2,58. SE). (Waluyo, $2011 ; 35$ ).

\subsection{Analisis Data}

Analisis data yang digunakan untuk menguji hipotesis adalah dengan Structural Equation Model (SEM). Menurut Waluyo (2011, 16 - 37), langkah-langkah pengujian hipotesis dengan SEM ada 7 yaitu:

Langkah 1 : Pengembangan Model Berdasarkan Teori; pengembangan model penelitian berdasarkan teori, penelitian terdahulu dan kerangka pemikiran yang sudah dijelaskan dalam tinjauan pustaka.

Langkah 2 : Pengembangan Diagram Alur (Path Diagram) untuk Menunjukkan Hubungan Kausalitas; Pengembangan tahap ini membantu menggambarkan serangkaian hubungan kasual antara konstruk dari model teoritis yang sudah dibangun pada tahap pertama menggunakan diagram alur (path diagram). Diagram alur yang akan dikembangkan dalam penelitian sebagai berikut: 


\section{Gambar 2}

Diagram Alur (Path Diagram)

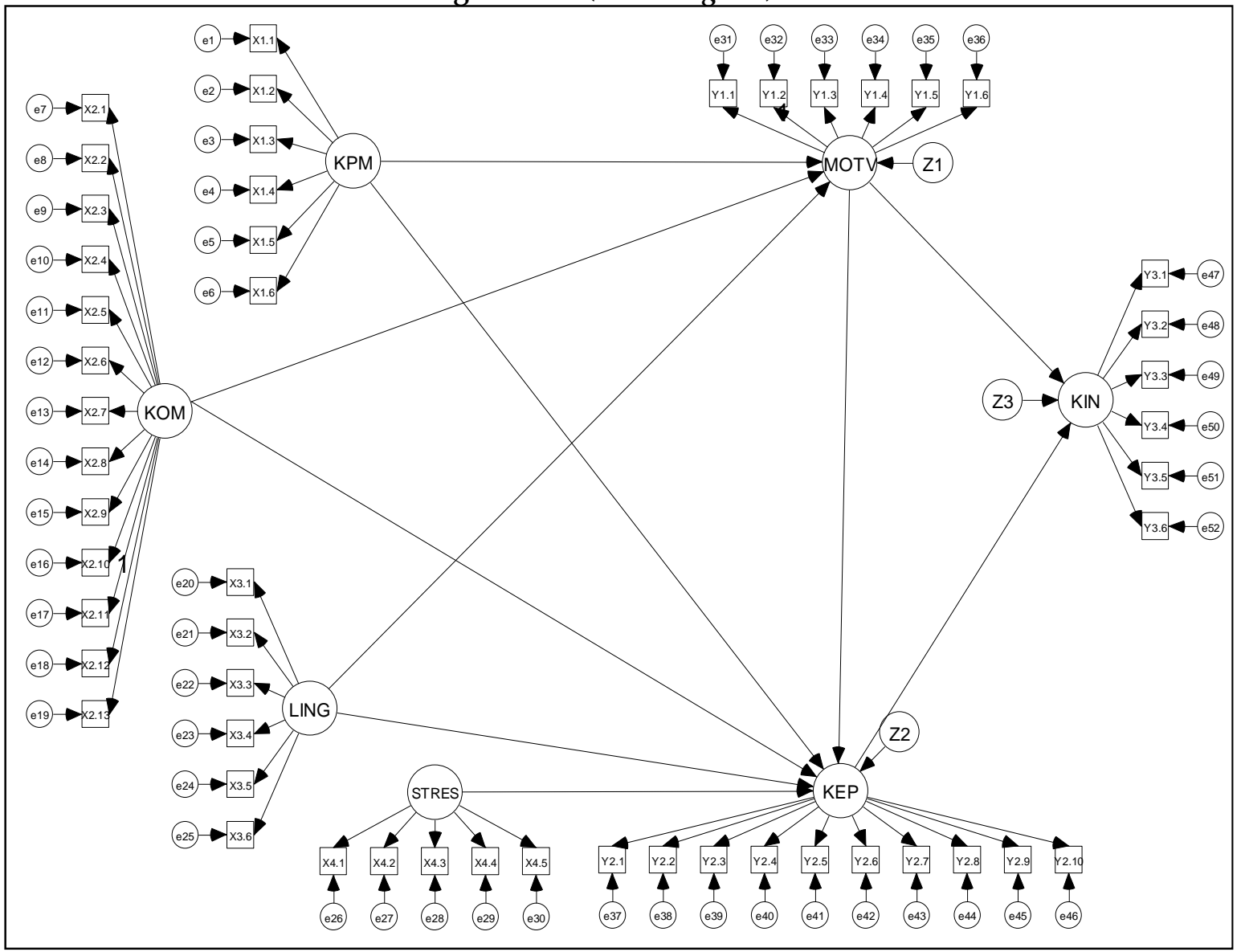

Langkah 3 : Konversi Diagram Alur ke dalam Serangkaian Persamaan Struktural dan Spesifikasi Model Pengukuran; Model yang telah dinyatakan dalam diagram alur kemudian dinyatakan dalam persamaan strukturalPersamaan Struktural dan Spesifikasi Model Pengukuran.

Langkah 4 : Pemilihan Matriks Input dan Teknik Estimasi Atas Model yang Dibangun; Matriks kovarian digunakan untuk penelitian yang menguji hubungan. Menurut Hair et all (2006), pengujian teori untuk memvalidasi hubungan - hubungan kausalitas menggunakan matriks varian/kovarian. Setelah itu menentukan teknik estimasi. Teknik estimasi yang akan digunakan adalah maximum likehood estimation method yaitu ukuran sampel antara 100 - 200 sampel atau ukuran sampel minimal sebesar 100 (Hair et all, 2006). Langkah 5 Menilai problem Identifikasi; Tahap ini menguji apakah pada model yang dikembangkan muncul problem ketidakmampuan model yang dikembangkan untuk menghasilkan estimasi yang baik.

Langkah 6 Evaluasi Model; Ketepatan model dievaluasi menggunakan kriteria goodness of fit. Evaluasi goodness of fit bertujuan untuk menilai seberapa baik model penelitian yang dikembangkan. Tahapan untuk mengevaluasi goodness of fit adalah evaluasi ukuran sampel, evaluasi asumsi normalitas dan linearitas, evaluasi outliers, evaluasi asumsi multikolinearitas dan singularitas dan evaluasi atas kriteria goodness of fit 
Kriteria goodness of fit;

\begin{tabular}{|c|c|}
\hline Goodness of Fit Indices & Cut-Off Value \\
\hline X2 Chi Square & Diharapkan kecil \\
\hline Probabilitas & $\geq 0,05$ \\
\hline CMIN/DF & $\leq 2,00$ \\
\hline RMSEA & $\leq 0,08$ \\
\hline GFI & $\geq 0,90$ \\
\hline AGFI & $\geq 0,90$ \\
\hline TLI & $\geq 0,95$ \\
\hline CFI & $\geq 0,95$ \\
\hline
\end{tabular}

Langkah 7 Interpretasi dan Modifikasi Model; Model yang baik memiliki standardized residual variance yang kecil. Apabila nilai standardized residual variance di luar ring $-2,58 \leq$ residual $\leq 2,58$ dan probabilitas (P) bila $<0,05$ maka model yang diestimasi perlu dilakukan modifikasi lebih lanjut dengan berpedoman pada indeks modifikasi yaitu dengan memilih Indeks Modifikasi (MI) yang terbesar dan landasan teori yang kuat akan memberi indikasi bahwa jika koefisien diestimasi maka akan terjadi pengecilan nilai chi square $\left(\mathrm{X}^{2}\right)$ yang signifikan.

\section{Hasil dan Pembahasan}

\subsection{Gambaran Umum Data Penelitian}

Penelitian ini dilaksanakan di Rumah Sakit Swasta yang ada di Kota Mataram tepatnya Rumah Sakit Internasional Harapan Keluarga. Jumlah respondensebanyak 150 orang. Semua kuesioner yaitu sebanyak responden 150 orang digunakan untuk menganalisis data atau tingkat respon rate $100 \%$. Data yang digunakan dalam penelitian ini terbagi menjadi 4 variabel eksogen yaitu Kepemimpinan (KEP), Kompensasi (KOM), Lingkungan Kerja (LNG) dan Stress Kerja (STR). Variabelendogen sebanyak 3 variabel yaitu Motivasi Kerja (MOT), Kepuasan Kerja (KPS) dan Kinerja (KIN). Adapun data hasil kuesioner terkait variabel yang digunakan terangkum dalam tabel 4.1 berikut:

Tabel 1

Deskripsi data Penelitian

\begin{tabular}{|r|c|c|c|c|c|c|c|}
\hline No & KEP & KOM & LNG & STR & MOT & KPS & KIN \\
\hline 1 & 0 & 1 & 1 & 17 & 1 & 1 & 0 \\
\hline 2 & 4 & 9 & 2 & 36 & 6 & 8 & 0 \\
\hline 3 & 21 & 29 & 13 & 41 & 26 & 28 & 13 \\
\hline 4 & 89 & 88 & 102 & 50 & 80 & 98 & 108 \\
\hline 5 & 36 & 23 & 32 & 6 & 37 & 15 & 29 \\
\hline Total & 150 & 150 & 150 & 150 & 150 & 150 & 150 \\
\hline
\end{tabular}

Sumber : data primer diolah (tahun 2014)

Hasil tabel 4.1 dapat dijelaskan bahwa kepemimpinan (KEP) paling banyak dijawab oleh responden adalah nilai 4 (setuju) sebanyak 89 responden atau 59\%, kemudian sangat setuju (nilai 5) sebanyak 36 orang atau $24 \%$. Sebanyak 11 orang atau $11 \%$ responden menjawab netral (nilai 3), 15 orang atau $15 \%$ menjawab tidak setuju (nilai 2) dan 1 orang menjawab sangat tidak setuju (nilai 1). 


\subsection{Uji Non Respon Bias}

Pengujian non-response biastidak dilakukan karena kuesioner dikembalikan responden sebelum tanggal yang ditetapkan (cut off) oleh penelitiyaitu 1 (satu) bulan.

\subsection{Uji Kualitas Data}

Hasil uji reliabilitas menunjukkan seluruh konstruk dalam penelitian ini lolos dalam uji sehingga dapat digunakan untuk mengolah data karena nilaiCronbach Alpha dari semua konstruk di atas 0,60. Hasil pengujian validitas menunjukkan semua konstruk sebanyak 52 (lima puluh dua)mempunyai nilai CR di atas 2,58 atau Validsehingga 52 pertanyaan tersebut bisa digunakan untuk analisis berikutnya.

\subsection{Uji Hipotesis}

\section{Gambar 3}

\section{Hasil Uji Structural Equation Model}

UJI HIPOTESIS

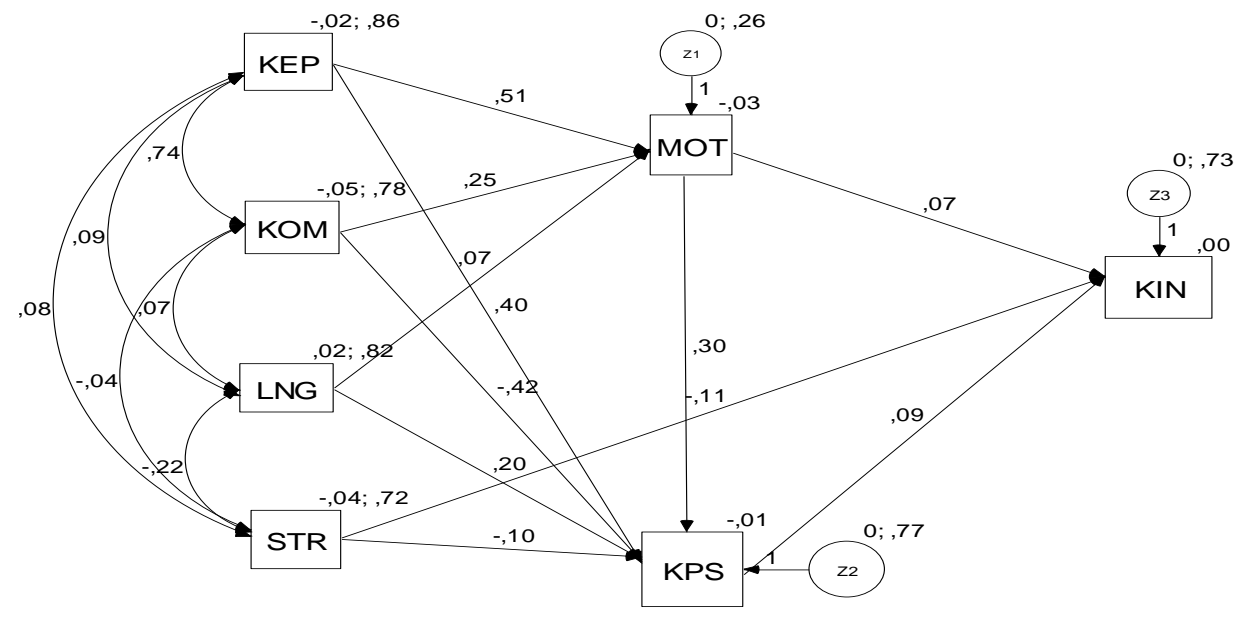

Tabel 2

Hasil Uji Structural Equation Model

\begin{tabular}{|c|c|c|c|}
\hline Kriteria & Cut Of Value & Hasil & Evaluasi \\
\hline $\mathrm{X}^{2}$ Chi Square & Diharapkan kecil & 38,128 & Baik \\
\hline Probabilitas & $\geq 0,05$ & 0,000 & Kurang Baik \\
\hline CMIN/DF & $\leq 2,00$ & 1,737 & Baik \\
\hline RMSEA & $\leq 0,08$ & 0,062 & Baik \\
\hline GFI & $\geq 0,90$ & 0,921 & Baik \\
\hline AGFI & $\geq 0,90$ & 0,986 & Baik \\
\hline TLI & $\geq 0,95$ & 0,972 & Baik \\
\hline CFI & $\geq 0,95$ & 0,854 & Marginal \\
\hline
\end{tabular}

Sumber : data primer diolah (tahun 2014)

Berdasarkan hasil pengamatan pada gambar 4.2 analisis full model dapat ditunjukkan bahwa model memenuhi kriteria fit, hal ini ditandai dengan nilai dari hasil perhitungan memenuhi kriteria layak full model. Hasil perhitungan uji chi - square pada full model diperoleh nilai chi square sebesar 38,128. Nilai probabilitas sebesar 0,000 yang mana nilai tersebut di bawah 0,05. Nilai CMIN/DF sebesar 1,737 di bawah 2,00. Nilai GFI sebesar 0,921 yaitu lebih besar dari 0,90, nilai 
AGFI sebesar 0,986 yaitu lebih besar dari 0,90. Nilai TLI sebesar 0,972 lebih besar dari 0,95. Nilai CFI sebesar 0,854 (marginal) lebih kecil dari 0,95 dan nilai RMSEA sebesar 0,062 yang mana nilai tersebut di di bawah 0,008 .

Hipotesis yang akan diuji dalam penelitian ini ada 10 (sepuluh), hasil pengujian hipotesis dalam penelitian ini dirangkum dalam tabel 4.3 berikut ini:

Tabel 3

Uji Hipotesis

\begin{tabular}{|c|c|c|c|c|c|c|c|}
\hline & & & Estimate & S.E. & C.R. & $\mathrm{P}$ & Label \\
\hline Motivasi & $<--$ & Kepemimpinan &, 507 & 102 & 4,979 & $* * *$ & par_1 \\
\hline Motivasi & $<-$ & Kompensasi & ,505 & 101 & 2,833 & $* * *$ & par_2 \\
\hline Motivasi & $<-$ & Lingkungan & ,071 & ,046 & 1,524 & 128 & par_3 \\
\hline Kepuasan & $<--$ & Kepemimpinan & ,505 & 103 & 2,612 & *** & par_4 \\
\hline Kepuasan & $<--$ & Kompensasi &,- 520 & 109 & $-2,822$ & $* * *$ & par_5 \\
\hline Kepuasan & $<--$ & Lingkungan &, 507 & ,084 & 2,654 & $* * *$ & par_6 \\
\hline Kepuasan & $<--$ & Stres &,- 096 & ,089 & $-1,077$ & 281 & par_7 \\
\hline Kepuasan & $<--$ & Motivasi & ,500 & 101 & 2,723 & $* * *$ & par_8 \\
\hline Kinerja & $<-$ & Motivasi & ,078 & ,086 & 907 &, 364 & par_9 \\
\hline Kinerja & $<-$ & Kepuasan & 111 & ,076 & 1,452 & 147 & par_10 \\
\hline
\end{tabular}

Hasil tabel 4.3 dapat menjelaskan semua hipotesis yang diajukan

Hipotesis 1: Pengaruh Kepemimpinan Terhadap Motivasi. Tabel 4.3 menunjukkan bahwa kepemimpinanberpengaruh terhadap motivasi. Hal ini terlihat dari nilai CR > 2,58 yaitu 4,979. Koefisien menunjukkan arah positif. Artinya karakter pemimpin yang mengayomi, memberikan bimbingan, arahan maupun dorongan, serta mampu berkomunikasi dengan baik dengan karyawan akan meningkatkan motivasi karyawan untuk bekerja. Hasil ini menerima hipotesis 1.

Hipotesis 2 : Pengaruh Kepemimpinan Terhadap Kepuasan. Tabel 4.3 menunjukkan bahwa kepemimpinanberpengaruh terhadap kepuasan. Hal ini terlihat dari nilai CR > 2,58 yaitu 2,612. Koefisien menunjukkan arah positif. Artinya karakter pemimpin yang berwibawa dan mempunyai hubungan yang baik dengan karyawan akan meningkatkan kepuasan karyawan. Hasil ini menerima hipotesis 2.

Hipotesis 3 : PengaruhKompensasi Terhadap Motivasi. Tabel 4.3 menunjukkan kompensasi berpengaruh terhadap motivasi. Hal ini terlihat dari nilai $C R>2,58$ yaitu 2.833. Koefisien menunjukkan arah positif. Artinya kompensasi finansial maupun non finansial yang tinggi akan meningkatkan motivasi karyawan untuk bekerja. Hasil ini menerima hipotesis 3.

Hipotesis 4 : PengaruhKompensasi Terhadap Kepuasan. Tabel 4.3 menunjukkan kompensasi berpengaruh terhadap kepuasan. Hal ini terlihat dari nilai $C R>2,58$ yaitu 2.822. Koefisien menunjukkan arah negatif. Artinya kompensasi finansial maupun non finansial belum memadai dengan pekerjaan yang diberikan sehingga menyebabkan motivasi karyawan untuk bekerja semakin rendah. Hasil ini menerimahipotesis 4.

Hipotesis 5 :Pengaruh Lingkungan Kerja Terhadap Motivasi. Tabel 4.3 menunjukkan lingkungan kerja tidak berpengaruh terhadap motivasi. Hal ini terlihat dari nilai $C R<2,58$ yaitu 1,524. Koefisien menunjukkan arah positif. Artinya kondisi lingkungan kerja belum memadai seperti ketersediaan fasilitas, kurangnya penerangan menyebabkan motivasi untuk bekerja berkurang. Hasil ini menolak hipotesis 5.

Hipotesis 6 :Pengaruh Lingkungan Kerja Terhadap Kepuasan. Tabel 4.3 menunjukkan lingkungan kerja berpengaruh terhadap kepuasan kerja. Hal ini terlihat dari nilai $C R>2,58$ yaitu 2,654 . Koefisien menunjukkan arah positif. Artinya kondisi lingkungan kerja yang memadai akan meningkatkan kepuasan karyawan. Hasil ini menerima hipotesis 6. 
Hipotesis 7: Pengaruh Stres terhadap Kepuasan. Tabel 4.3 menunjukkan stres tidak berpengaruh terhadap kepuasan kerja. Hal ini terlihat dari nilai $C R<2,58$ yaitu 1,077. Koefisien menunjukkan arah negatif. Artinya stres yang dihadapi karyawan masih rendah sehingga tidak mempengaruhi kepuasan karyawan. Hasil ini menolak hipotesis 7.

Hipotesis 8 (delapan) dan 10 (sepuluh) menguji pengaruh variabel intervening. Variabel intervening adalah variabel untuk melihat seberapa kuat pengaruh suatu variabel dengan variabel lainnya baik secara langsung maupun secara tidak langsung. Interpretasi dari hasil ini akan memiliki arti yang penting untuk mendapatkan suatu pemilihan strategi yang jelas, sesuai dengan kajian teoritis dan hasil pengujian hipotesis. Hasil pengujian pengaruh langsung, tidak langsung dan pengaruh total tersebut dapat di lihat pada pengujian hipotesis 8 (delapan) sampai 10 (sepuluh) berikut:

Hipotesis 8 : Pengaruh stres terhadap kinerja melalui kepuasan

Gambar 3

Diagram Alur Pengaruh stres terhadap kinerja dengan Kepuasan Sebagai Variabel Intervening

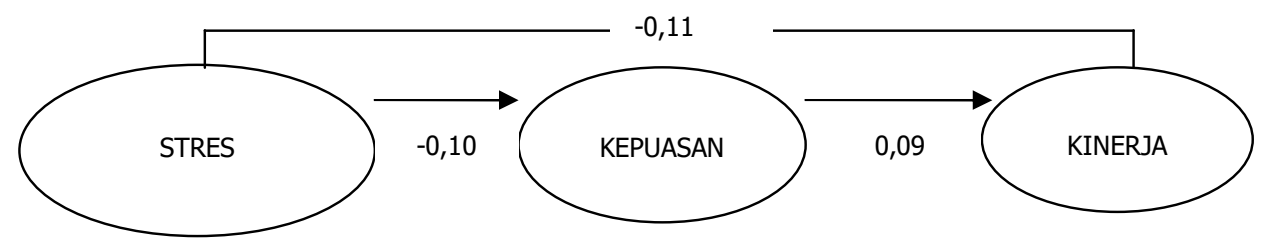

Hasil koefisien pada gambar 4.2 menunjukkan pengaruh langsung, tidak langsung, dan pengaruh total dari stress kerja terhadap kinerja. Perhitungan pengaruh langsung, tidak langsung dan total stres terhadap kinerja ditunjukkan pada tabel 4.3 berikut:

Tabel 3

Pengaruh Langsung, Tidak Langsung dan Total Stres terhadap Kinerja

\begin{tabular}{|l|c|c|c|}
\hline & $\begin{array}{c}\text { Pengaruh } \\
\text { Langsung }\end{array}$ & $\begin{array}{c}\text { Pengaruh } \\
\text { Tidak } \\
\text { Langsung }\end{array}$ & $\begin{array}{c}\text { Pengaruh } \\
\text { Total }\end{array}$ \\
\hline Pengaruh Stres Terhadap Kinerja & $-0,11$ & & \\
\hline $\begin{array}{l}\text { Pengaruh Stres terhadap Kinerja } \\
\text { melalui kepuasan }\end{array}$ & $-0,10$ & $\begin{array}{c}-0,10 \times 0,09 \\
=-0,009\end{array}$ & $-0,119$ \\
\hline $\begin{array}{l}\text { Pengaruh Stres kerja terhadap } \\
\text { Kepuasan }\end{array}$ & & \\
\hline
\end{tabular}

Sumber : data primer diolah (tahun 2014)

Hasil gambar 4.2 dan tabel 4.3 menunjukkan perhitungan pengaruh langsung maupun pengaruh tidak langsung stres terhadap terhadap kinerja.Pengaruh langsung stres terhadap kinerja adalah -0,11; pengaruh tidak langsung stres terhadap kinerja sebesar -0,009 sehingga pengaruh total dari stres terhadap kinerja -0,119. Hasil ini menolak hipotesis 8, artinya strestidak mempengaruhi hubungan kinerja melalui kepuasan kerja. Stres yang dialami oleh karyawan masih kecil (dalam batas wajar) sehingga tidak mempengaruhi kepuasan dan kinerja.

Hipotesis 9 :Pengaruh Motivasi Terhadap Kinerja. Tabel 4.3 menunjukkan motivasi tidak berpengaruh kinerja. Hal ini terlihat dari nilai $C R<2,58$ yaitu 0,907 . Koefisien menunjukkan arah positif. Artinya motivasi yang tinggi akan meningkatkan kinerja. Tetapi kondisi dilapangan menunjukkan kurangnya motivasi disebabkan berbagai hal sehingga kinerja juga kurang. Hasil ini menolak hipotesis 9 .

\section{Hipotesis 10 : Pengaruh Motivasi Terhadap Kinerja Melalui Kepuasan}


Gambar 4.4 berikut menjelaskan pengaruh motivasi terhadap kinerja melalui kepuasan

Gambar 4

Diagram Alur Pengaruh Motivasi terhadap kinerja dengan Kepuasan Sebagai Variabel Intervening

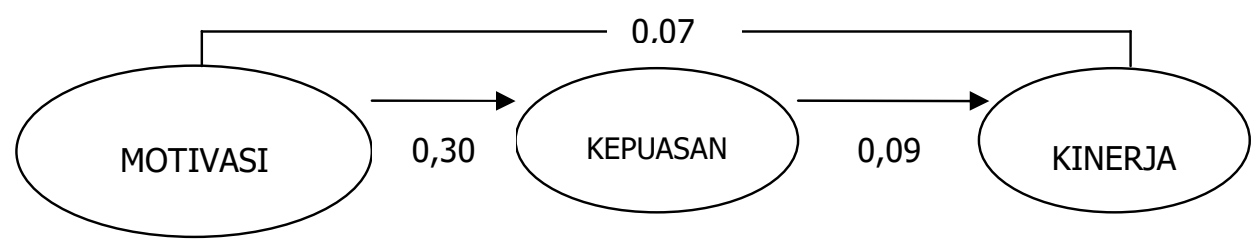

Hasil koefisien pada gambar 4.4 menunjukkan pengaruh langsung, tidak langsung,

dan pengaruh total dari motivasi terhadap kinerja. Perhitungan pengaruh langsung, tidak langsung dan total Motivasi terhadap kinerja ditunjukkan pada tabel 4.4 berikut:

Tabel 4

Pengaruh Langsung, Tidak Langsung dan Total Motivasi terhadap Kinerja

\begin{tabular}{|l|c|c|c|}
\hline & $\begin{array}{c}\text { Pengaruh } \\
\text { Langsung }\end{array}$ & $\begin{array}{c}\text { Pengaruh Tidak } \\
\text { Langsung }\end{array}$ & $\begin{array}{c}\text { Pengaruh } \\
\text { Total }\end{array}$ \\
\hline Pengaruh motivasi terhadap kinerja & 0,07 & & \\
\hline $\begin{array}{l}\text { Pengaruh motivasi } \\
\text { terhadapkinerjamelalui kepuasan }\end{array}$ & & $\begin{array}{c}0,30 \times 0,09 \\
=0,027\end{array}$ & 0.097 \\
\hline Pengaruh kepuasan terhadap kinerja & 0,09 & & \\
\hline
\end{tabular}

Sumber : data primer diolah (tahun 2014)

Hasil gambar 4.3 dan tabel 4.3 menunjukkan perhitungan pengaruh langsung maupun pengaruh tidak langsung motivasi terhadap kinerja.Pengaruh langsung motivasi terhadap kinerja adalah 0,07; pengaruh tidak langsung motivasi terhadap kinerja sebesar 0,027 sehingga pengaruh total dari motivasi terhadap kinerja sebesar 0,097. Hasil ini menolak hipotesis 10, artinya motivasi tidak mempengaruhi hubungan kinerja melalui kepuasan. Motivasi sangat rendah sehingga kepuasan juga rendah yang pada akhirnya menyebabkan kinerja juga rendah.

\subsection{Interpretasi}

Salah satu faktor yang menentukan seseorang untuk bekerja adalah motivasi.Selama ini kinerja dianggap akan meningkat jika motivasi juga tinggi. Motivasi yang tinggi dipengaruhi oleh berbagai hal, diantaranya fasilitas yang memadai dalam suatu kantor/perusahaan, gaya pimpinan, kompensasi yang diberikan di tempat kerja serta lingkungan kerja itu sendiri. Apabila faktor-faktor motivasi tersebut terpenuhi maka secara otomatis akan meningkatkan kepuasan karyawan yang pada akhirnyameningkatkan kinerja.

Stres kerja merupakan kondisi yang muncul sebagai akibat dari interaksi antara individu dengan pekerjaan. Stres bisa menyebabkan efek positif maupun negatif tergantung dari individu tersebut. Jika individu tersebut tidak bisa memanage stres maka akan menyebabkan masalah yang bisa mengganggu kesehatan. Sebaliknya jika individu itu bisa memanage stres maka akan menyebabkan individu tersebut termotivasi untuk melakukan pekerjaannya sampai mereka puas dengan pekerjaan itu.

Hasil penelitian menunjukkan kepemimpinan dan kompensasi berpengaruh positif terhadap motivasi. Kompensasi yang tinggi akan meningkatkan motivasi seseorang untuk bekerja. Hal ini sesuai dengan pendapat Ivanchevich et all (2008) dan Potu bahwa reward (bonus dan tunjangan) dari perusahaan akan memotivasi karyawan untuk bekerja. Gaya pemimpin sangat 
mempengaruhi motivasi karyawan. Pemimpin yang suka memberikan perhatian, dukungan dan pujian kepada karyawan akan membuat karyawan termotivasi untuk bekerja dan menghasilkan karya yang baik.Hasil ini mendukungpendapat Fisher dan Rubenstein yang dikutip Sulaimiah (2005) dan Adianto, dkk (2005) : jika kinerja karyawan baik makaseorang pimpinan harus menciptakan hubungan yang baik dengan karyawan.

Kepuasan kerja dipengaruhi pengarahan yang diberikan oleh atasan (kepemimpinan) dan lingkungan kinerja.Semakin sering pimpinan memberikan pengarahan terkait dengan tugas maupun tanggungjawab menyebabkan karyawan merasa diperhatikan oleh pimpinan sehingga meningkatkan kepuasan karyawan.Lingkungan kerja yang mendukung seperti ketersediaan fasilitas yang memadai akan meningkatkan kepuasan karyawan. Namun disisi lain lingkungan kerja tidak mempengaruhi motivasi kemungkinan disebabkan fasilitas yang tersedia masih terbatas jumlahnya. Berdasarkan hasil pengamatan langsung di rumah sakit Harapan Keluarga, fasilitasnya masih kurang dibandingkan dengan besarnya rumah sakit dan nama besar sebagai rumah sakit internasional jauh dari kata memadai.

Kompensasi dan stres berpengaruh negatif terhadap kepuasan. Hal ini kemungkinan disebabkan kompensasi yang diberikan kepada karyawan masih jauh dari kata layak untuk ukuran rumah sakit bertaraf internasional. Stres yang dialami karyawan masih rendah sehingga tidak mempengaruhi kepuasan karyawan. Hal ini didukung dengan kondisi di lapangan bahwa pasien yang datang berobat jalan maupun opname ke rumah sakit Harapan Keluarga tidak seramai rumah sakit swasta lainnya seperti Risa Klinik sehingga tidak menimbulkan stres kepada karyawan. Stres yang dialami masih rendah. Hasil penelitian ini bertolak belakang dengan Teori Herzberg (1966), salah satu faktor yang mendorong individu untuk berusaha mencapai kepuasan dan menjauhkan diri dari ketidakpuasan adalah imbalan (kompensasi). Ketika kompensasi tinggi maka kepuasan juga akan tinggi.

Motivasi tidak berpengaruh terhadap kinerja. Hal ini disebabkan motivasi karyawan untuk bekerja masih rendah disebabkan sumber motivasi yang belum memadai. Sebagian besar orang akan termotivasi untuk bekerja jika diberikan reward maupun bonus yang tinggi namun kondisi di lapangan tidak menunjukkan hal yang demikian.

\section{Simpulan Dan Saran}

\subsection{Simpulan}

Berdasarkan hasil penelitian dan interpretasi pada bab sebelumnya, maka dapat ditarik simpulan sebagai berikut:

1. Kepemimpinan berpengaruh positif terhadap motivasi dan kepuasan. Pemimpin yang sering memperhatikan karyawan, memberi rasa aman dan sering memberikan arahan akan tugas/kewajiban akan memotivasi karyawan untuk bekerja sehingga karyawan akan merasa puas akan pekerjaannya.

2. Kompensasi berpengaruh positif terhadap motivasi. Semakin tinggi kompensasi yang diberikan perusahaan baik berupa reward maupun bonus akan meningkatkan motivasi karyawan. Karyawan merasa lebih dihargai jika kompensasi itu diberikan dalam bentuk materi dibandingkan dalam bentuk promosi ke jenjang yang lebih tinggi. Namun disisi lain kompensasi berpengaruh negatif terhadap kepuasan. Karyawan akan merasa puas apabila kompensasi yang diberikan sesuai dengan pekerjaan yang diberikan. Dengan kata lain kompensasi yang diberikan tidak sesuai dengan nama besar Rumah Sakit Harapan Keluarga yaitu sebagai rumah sakit internasional. Untuk ukuran internasional kompensasinya masih kurang sehingga karyawan belum puas. 
3. Lingkungan berpengaruh positif terhadap kepuasan kerja tetapi tidak berpengaruh terhadap motivasi. Lingkungan kerja yang nyaman dengan fasilitas yang memadai akan meningkatkan kepuasan karyawan. Rumah Sakit dengan taraf internasional belum menyediakan fasilitas yang memadai bagi karyawan sehingga tidak membuat karyawan termotivasi untuk bekerja.

4. Stres tidak berpengaruh terhadap kepuasan. Stres yang dialami perawat di bagian rawat inap masih rendah sehingga tidak mempengaruhi kepuasan mereka. Rendahnya stres dikarenakan Rumah Sakit Harapan Keluarga belum mempunyai pasien yang banyak. Stres yang rendah tidak mempengaruhi kinerja karena kepuasan juga rendah.

5. Motivasi tidak berpengaruh terhadap kinerja. Kinerja sangat ditentukan oleh motivasi, apabila motivasi sangat rendah maka kinerja juga akan rendah. Sumber-sumber motivasi belum memadai seperti kompenasasi yang masih rendah sehingga tidak meningkatkan kinerja karyawan. Motivasi yang rendah akan mengakibatkan kepuasan kerja rendah sehingga kinerja juga akan rendah.

\subsection{Saran}

Berdasarkan hasil penelitian, ada 2 hal yang perlu dipertimbangkan sebagai saran, yaitu:

1. Bagi Manajemen Rumah Sakit : Perlu dikaji ulang terkait dengan kompensasi yang diberikan kepada karyawan. Kompensasi yang memadai akan meningkatkan kepuasan karyawan sehingga akan mempengaruhi kinerjanya. Perlunya penambahan fasilitas sebagai ukuran dari lingkungan kerja sehingga fasilitas yang disediakan sesuai dengan namanya sebagai rumah sakit bertaraf internasional.

2. Peneliti Selanjutnya: penelitian hanya dilakukan pada satu rumah sakit saja yaitu Rumah Sakit Harapan Keluarga. Selanjutnya dapat memperluas wilayah penelitian yaitu semua rumah sakit yang ada di Kota Mataram

\section{Daftar Pustaka}

Adianto, Hari. Yuke Agustin, I.G.A. Happy Trindira. 2005. Jurnal Manajemen E Kewirausahaan, Vol. 7, No. 2, September 2005: 125-138

Adrian Furnham and Andreas Eracleous. 2009. Personality, motivation and job satisfaction: Hertzberg meets the Big Five. Journal of Managerial Psychology Vol. 24 No. 8, pp. 765-779

Arvey, R.D., Bouchard, T.J., Segal, N.L. and Abraham, L.M. 1989, “Job satisfaction: environmental and genetic components", Journal of Applied Psychology, Vol. 74, pp. 187-92.

Bass, B.M dan Avolio, 1990, The Implications of Transaksional and Transformational, Team and Organization Development, 4, p.231-273

Borchgrevink, C.P. 2004, "Leader-member exchange in a total service industry: the hospitality industry business", in Graen, G.B. (Ed.), New Frontiers of Leadership, Information Age Publishing, Greenwich, CT.

Conger, J.A. 1991. "Inspiring others: the language of leadership", The Executive, Vol. 5, pp. 31-45.

Dwiyanti, Endang. 2011. Stres Kerja di Lingkungan DPRD : Studi Tentang Anggota DPRD di Kota Surabaya, Malang dan Kabupaten Jember. Jurnal Masyarakat, Kebudayaan dan Politik. Vol 3. p. $73-84$

Vafaei, M. 2000. Teachers' stress: Prevalence, sources, and consequences of occupational stress among primary and secondary school teachers. Psychology Journal, 6(1-2), 63-91.

Farzadfar, F., Hadadi, M., Naeli, J., Haghighi, D., \& Mollashikhi, M. 2005. Performance monitoring of health system managers (1st ed.). Iran's Health Ministry, Tehran: Andishmand.

Goleman, D., Boyatzis, R.E. and McKee, A. 2002. The New Leaders: transforming the Art of Leadership into the Science of Results, Little, Brown, London. 
Goleman, D., Boyatzis, R.E. and McKee, A. 2004. Primal Leadership: Learning to Lead with Emotional Intelligence, Harvard Business School Press, Boston, MA, p. 336.

Hair, Joseph, F., William C. Black, Barry J. Babin, Rolph E. Anderson and Ronald L. Tatham. 2006. Multivariate Data Analysis. Sixth Edition. Pearson International Edition

Hamidi Yadollah and Zahra Eivazi. 2010. The Relationships among Employees' Job Stress, Job Satisfaction, and the organizational Performance of Hamadan Urban Health Centers. Social Behavior And Personality, 2010, 38(7), 963-968

Henderson, D.J., Dulac, T. and Liden, R.C. 2006. "The role of LMX and communication in the goal setting process", in Graen, G.B. and Graen, J.A. (Eds), Sharing Network Leadership: LMX Leadership, The Series, Vol. 4, Information Age Publishing, Greenwich, CT, pp. 245-68.

Henderson, D.J., Wayne, S.J., Shore, L.M., Bommer, W. and Tetrick, L.E. 2008. "Leader-member exchange, differentiation, and psychological contract fulfillment: a multilevel examination", Journal of Applied Psychology, Vol. 93 No. 6, p. 1208.

Herzberg, F., Mausner, B. and Snyderman, B.B. 1959. The Motivation to Work, 2nd ed.,John Wiley \& Sons, New York, NY.

Ivancevich, John M., Roberth Konopaske and Michael T. Matteson. 2008. Organizational Behavior and Management. Eight Edition. Mc Graw-Hill International Edition

Johansson G. 2007. The Illness Flexibility Model and Sickness Absence (Doctoral thesis). Karolinska Institutet, Stockholm.

Kramer, M.W. 2006 "Communication strategies for sharing leadership within a creative team: LMX in theater groups", Sharing Network Leadership, LMX Leadership: The Series, Vol. 4, Information Age Publishing, Greenwich, CT, pp. 1-24.

Luthans, Fred. 2006. Organizational Behavior. New York : McGraw-Hill

Mayfield, J. and Mayfield, M. 2007, "The effects of leader communication on a worker's intent to stay: an investigation using structural equation modeling", Human Performance, Vol. 20 No. 2, pp. 85-102.

Mayfield Jacqueline and Milton Mayfield. 2010. Leader-level influence on motivating language A two-level model investigation on worker performance and job satisfaction. Competitiveness Review: An International Business Journal Vol. 20 No. 5, 2010 pp. 407-422

Potu Aurelia. 2013. Kepemimpinan, Motivasi, Dan Lingkungan Kerja Pengaruhnya Terhadap Kinerja Karyawan Pada Kanwil Ditjen Kekayaan Negara Suluttenggo Dan Maluku Utara Di Manado. Jurnal Emba Vol.1 No.4 Desember 2013, Hal. 1208-1218

Sari Rahmila, Mahlia Muis, Nurdjannah Hamid. 2012. Pengaruh Kepemimpinan, Motivasi, Dan Stres Kerja Terhadap Kinerja Karyawan Pada Bank Syariah Mandiri Kantor Cabang Makassar. Diunduh tanggal $\quad 5 \quad$ Februari 2014.http:// pasca.unhas.ac.id/jurnal/files/8f8285a8d250d738502b4d19dfdb30c2.pdf.

Sulaimiah. 2005. Pengaruh Stressor Individual, Kepribadian Terhadap Stres Kerja Dan Kinerja Karyawan Operasional Perbankan di Mataram Nusa Tenggara Barat. Thesis. Unpublished. Universitas Airlangga. Surabaya

Sulaimiah. Wahidatul Husnaini, Zuhrotul Isnaini, Isnawati dan Wanharul Akbar. 2013 Pengaruh Konflik Peran Ganda Dan Kepemimpinan Terhadap Kinerja Dengan Stress Kerja Sebagai Variabel Intervening. Jurnal Riset Manajemen. Vol 13 No. 1 Maret, p. 21-42

Sullivan, J. (1988), "Three roles of language in motivation theory", Academy of Management Review, Vol. 13 No. 1, pp. 104-15.

Stringer Carolyn Jeni Didham, and Paul Theivananthampillai. 2011. "Motivation, pay satisfaction, and job satisfaction of front-line employees" Qualitative Research in Accounting E Management Vol. 8 No. 2, 2011pp. 161-179

Solimun. 2007. Memahami Metode Kuantitatif Mutakhir Struktur Equation Modeling \& Partial Least Squere. Modul Pelatihan Pemodelan Persamaan Struktural Pendekatan SEM dan PLS di Universitas Mataram. Juni 2007. 
Surati, Sulaimiah, Wahidatul Husnaini, Zuhrotul Isnaini, Rahmat Fakhrurrozi. 2013. Pengaruh Karakteristik Individu, Karakteristik Pekerjaan Dan Dukungan Sosial Terhadap Kepuasan Kerja Dengan Stres Kerja Sebagai Variabel Intervening. Laporan Penelitian. Unpublished. Program Magister Manajemen Universitas Mataram

Raeissi, P., \& Tavakoli, G. H. 2002. The impact of occupational stress on mental health and job performance in hospital managers and matrons. Hakim, 4(5), 247-254.

Van Herpen, M., Van Praag, M. and Cools, K. 2005, "The effects of performance measurement and compensation on motivation: an empirical study", De Economist, Vol. 153 No. 3, pp. 303-29.

Vecchio, Robert, P. 2003. Organizaiotnal Behavior Core Concepts. $5^{\text {th }}$ Edition. Thomson, South Western.

Waluyo, Minto. 2011. Panduan Dan Aplikasi Structural Equation Modelling(Untuk Aplikasi Model Dalam Penelitian Teknik Industri, Psikologi, Sosial dan Manajemen). PT. Indeks. Jakarta

Yukl, Gary A, 1989. Managerial Leadership: A Review of Theory and Research, Journal of Management, Vol 15, No.2, 251-289.

Zahedi, M. R., Palahang, H., \& Ghafari, M. 2000. Study of job satisfaction of health workers in Charmahal - Bakhtiari Province. Shahrekord University of Medical Sciences, 2(1), 27-33 